\title{
Persepsi Mahasiswa Tingkat Dasar dalam Membedakan Nada Kedua dan Ketiga Bahasa Mandarin
}

\author{
Nanda Lailatul Qadriani ${ }^{1}$, Tri Budianingsih ${ }^{1}$ \\ ${ }^{1}$ Program studi Bahasa Mandarin dan Kebudayaan Tiongkok, Fakultas Ilmu Pengetahuan Budaya, \\ Universitas Al Azhar Indonesia, Jl. Sisingamangaraja, Kebayoran Baru, Jakarta Selatan, 12110 \\ Penulis untuk Korespondensi/E-mail: nanda.lailatul@uai.ac.id
}

\begin{abstract}
This research aims to determine the types of perceptions of basic level students in distinguishing the tone 2 and tone 3 in Chinese, whether classified as category perception or continuum perception. The method used in this study is divided into classifying tests and determining tests. Participants were 18 first-semester students with a basic Chinese level. The results of this study show that the perceptions of students with basic Chinese levels are classified as continuum perception. The results of the first test show that students perceive a category boundary between tone 2 and tone 3 , but it's not significant. In the second test, the accuracy of students' answers in distinguishing whether or not the tone heard was very low. The level of sensitivity of students in differentiating up-and-down sound stimuli that characterizes tone 2 and tone 3 in Chinese is also still low.
\end{abstract}

Abstrak - Artikel ini bertujuan untuk mengetahui jenis persepsi mahasiswa tingkat dasar dalam membedakan nada kedua dan ketiga dalam bahasa mandarin, apakah tergolong jenis category perception atau continuum perception. Metode yang digunakan adalah metode tes yang terbagi menjadi tes penggolongan stimulus bunyi dan tes penentuan sama atau tidaknya sepasang stimulus bunyi yang diperdengarkan. Peserta dari penelitian ini adalah 18 orang mahasiswa semester 1 dengan tingkat kemampuan bahasa Mandarin dasar. Hasil penelitian menunjukkan jenis persepsi mahasiswa dengan kemampuan berbahasa Mandarin tingkat dasar tergolong persepsi kontinuitas (continuum perception). Ini dikarenakan hasil tes penggolongan bunyi menunjukkan mahasiswa mempersepsi adanya batasan kategori antara nada kedua dan ketiga, namun tidak signifikan. Pada tes, ketepatan jawaban mahasiswa dalam membedakan sama atau tidaknya nada yang didengar sangat rendah. Selain itu, tingkat kepekaan mahasiswa dalam membedakan stimulus-stimulus bunyi turun-naik yang menjadi ciri nada kedua dan ketiga dalam bahasa Mandarin juga masih rendah.

Keywords - Categorical perception; Second-tone; Third-tone; Chinese language

\section{PENDAHULUAN}

$\mathrm{S}$ ama halnya dengan vokal dan konsonan, nada juga merupakan salah satu komponen yang sangat penting dalam pelafalan bahasa Mandarin. Jika satu kata memiliki nada yang berbeda, maka artinya akan berbeda pula. Hal ini menjadi salah satu kesulitan pelajar di Indonesia dalam mempelajari bahasa Mandarin dikarenakan dalam bahasa Indonesia perbedaan nada atau intonasi dalam kata tidak banyak mempengaruhi arti dari kata tersebut.

Berdasarkan hasil penelitian Wang Gongping [1] dan Wang Maolin [2] disebutkan bahwa nada kedua dan ketiga adalah nada yang paling sulit dikuasai oleh pembelajar bahasa Mandarin asal Indonesia baik yang mempelajari bahasa Mandarin langsung di Tiongkok maupun di sekolah atau universitas di Indonesia. Hal ini dikarenakan bentuk nada (调型) kedua dan ketiga cukup mirip yakni bentuk kurva turun-naik. Meskipun dalam pembelajaran bahasa Mandarin, nilai nada kedua (调值) yang sering diajarkan adalah 35 atau nada naik, namun dalam ilmu fonetik dijelaskan bahwa dalam pengucapannya setiap nada pasti diawali dengan nada datar atau turun terlebih dahulu kemudian 
mengikuti bentuk nada aslinya (datar, naik, turunnaik atau turun). [3]

Beberapa metode digunakan untuk mengetahui karakteristik penutur asing dalam menguasai nadanada dalam bahasa Mandarin, misalnya dengan cara menganalisis lafal penutur asing saat membaca kata/kalimat, meminta penutur asing untuk menganalisis nada dari kata yang didengar serta memperdengarkan serangkaian stimulus bunyi dengan variabel tertentu kepada penutur asing dan meminta mereka untuk mempersepsinya menjadi suatu jenis nada tertentu. Metode persepsi inilah yang menjadi pembahasan dalam penelitian ini.

Penelitian tentang persepsi pendengar pada nada dalam suatu bahasa adalah gabungan dari ilmu fonologi, psikologi dan linguistik kognitif. Salah satu teori yang digunakan dalam penelitian terhadap persepsi pada nada adalah categorical perception. Yang dimaksud dengan categorical perception adalah seluruh perubahan bunyi yang berkesinambungan dirasakan seperti kelompokkelompok bunyi yang terpisah dan terbatas jumlahnya. Kategori/kelompok bunyi ini juga disebut sebagai suku kata（音节）.

Teori categorical perception pertama kali disampaikan oleh Liberman. Liberman menggunakan stimulus bunyi konsonan $\mathrm{b}, \mathrm{d}$ dan $\mathrm{g}$ dalam bahasa Inggris, Liberman menyebutkan bahwa antar konsonan dalam bahasa Inggris terdapat suatu batasan yang menyebabkan konsonan itu menjadi terkelompok-kelompok. Dia menambahkan suatu bunyi dalam kelompok/kategori yang sama akan sulit dibedakan, namun pendengar akan lebih sensitif terhadap kategori bunyi yang berbeda. Penelitian terhadap persepsi pada nada dalam bahasa Mandarin dilakukan pertama kali oleh Wang Shiyuan. Wang Shiyuan menyatakan di antara nada pertama dan nada kedua dalam bahasa mandarin terdapat batasan kategori. Sejak saat itu, penelitian tentang nada yang melibatkan penutur asli maupun asing bahasa Mandarin mulai bermunculan. [4]

Beberapa hasil penelitian dengan penutur asing atau pembelajar bahasa mandarin sebagai subjek penelitian adalah penelitian yang dilakukan oleh Zhang Linjun, Li Leqin, Tao Chongzi, Wang Yunjia, Li Meijing dan Nanda L Qadriani. Zhang Linjun meneliti mahasiswa asing dengan kemampuan bahasa mandarin nol asal Korea Selatan, Thailand dan Jepang terhadap jenis persepsi mereka pada nada dalam bahasa mandarin. Hasil penelitiannya menyatakan persepsi mahasiswa asal Korea Selatan dan Jepang tergolong persepsi kontinuitas (continuum perception), sedangkan persepsi mahasiswa asal Thailand tergolong persepsi terkategori (categorical perception), hanya saja jenis persepsi kategorinya memiliki sedikit perbedaan dengan penutur asli bahasa Mandarin asal Tiongkok. [5]

Li Leqin (2014) meneliti mahasiswa asal Vietnam dan Thailand. Kedua negara ini memiliki bahasa nasional yang juga mempunyai nada seperti halnya bahasa Mandarin. Hasil penelitian Li menyebutkan baik mahasiswa asal Vietnam atau Thailand keduanya mendapatkan pengaruh dari bahasa nasional mereka masing-masing. Mahasiswa asal Vietnam sulit untuk membedakan nada pertama dan keempat dalam bahasa mandarin, sedangkan mahasiswa asal Thailand sulit membedakan nada pertama dan kedua. Ini menunjukkan bahwa jenis persepsi mereka terhadap nada dalam bahasa mandarin tergolong kategori kontinuitas (continuum perception). [6]

Tao Chongzi membandingkan jenis persepsi mahasiswa Tiongkok dengan mahasiswa Indonesia tingkat dasar dan atas terhadap stimulus bunyi nada pertama-kedua, nada kedua-keempat dan nada ketiga-keempat. Hasil penelitiannya menyatakan mahasiswa Indonesia tingkat dasar meskipun tidak menunjukkan jenis categorical perception, namun pendengaran mereka cukup sensitif terhadap tinggi nada pada ujung dan pangkal stimulus bunyi, sedangkan mahasiswa Indonesia tingkat atas sudah menunjukkan kecenderungan pada jenis categorical perception. [7]

Pada penelitian sebelumnya diketahui masalah terbesar mahasiswa Indonesia dalam belajar bahasa mandarin adalah pada nada kedua dan ketiga. Beberapa peneliti yang menggunakan stimulus bunyi turun-naik（降升调） dalam penelitiannya tentang jenis persepsi pada nada kedua dan ketiga adalah Wang Yunjia dan Li Meijing. Hasil penelitian mereka menunjukkan jenis persepsi mahasiswa Tiongkok terhadap nada kedua dan ketiga adalah categorical perception [8], sedangkan jenis persepsi mahasiswa asal Korea Selatan dengan kemampuan bahasa mandarin tingkat dasar dan atas adalah continuum perception. [9]

Nanda L Qadriani melakukan penelitian tentang jenis persepsi mahasiswa Indonesia tingkat atas (semester 8) terhadap nada kedua dan ketiga bahasa Mandarin dengan menggunakan stimulus bunyi 
turun-naik（降升调） dengan variabel bebas frekuensi dan letak/waktu titik lekuk. Hasil penelitiannya menyatakan mahasiswa Indonesia tingkat atas memiliki kecenderungan categorical perception meskipun tingkat kesensitifan terhadap perbedaan bunyi yang didengar tidak sebaik mahasiswa Tiongkok. [10]

Dari hasil penelitian di atas dapat diketahui bahwa asal negara dan tingkat kemampuan bahasa Mandarin penutur asli maupun asing dapat mempengaruhi persepsi mereka terhadap nada yang didengar. Penelitian ini merupakan kelanjutan dari penelitian yang Nanda L Qadriani lakukan sebelumnya. Dengan bahan penelitian yang sama, penelitian ini bertujuan untuk mengetahui jenis persepsi mahasiswa dengan kemampuan bahasa Mandarin tingkat dasar dalam membedakan nada kedua dan ketiga dalam bahasa mandarin. Jika mahasiswa tingkat atas memiliki kecenderungan jenis persepsi seperti penutur asli bahasa Mandarin, bagaimana dengan jenis persepsi mahasiswa Indonesia tingkat dasar terhadap nada kedua dan ketiga, apakah categorical perception atau continuum perception? Apakah mahasiswa tingkat dasar peka terhadap perubahan dan perbedaan letak dan waktu titik lekuk dalam stimulus nada turunnaik?

\section{METODE}

Metode atau teknik pengumpulan data dalam penelitian ini dilakukan dengan metode tes. Peneliti terlebih dahulu mempersiapkan serangkaian stimulus bunyi turun-naik (降升调) dengan titik awal dan akhir tetap, yakni masing-masing $174 \mathrm{~Hz}$ dan $240 \mathrm{~Hz}$, total panjang nada $360 \mathrm{~ms}$. Stimulus bunyi ini disusun dengan memvariasikan frekuensi dan waktu titik lekuk. Variasi frekuensi pada titik lekuk adalah $10 \mathrm{~Hz}-75 \mathrm{~Hz}$. Selisih frekuensi setiap stimulus bunyi sebesar $5 \mathrm{~Hz}$, sehingga dihasilkan 14 varian stimulus bunyi. Sedangkan variasi pada letak/waktu titik lekuk dimulai dari waktu $20 \mathrm{~ms}-$ $240 \mathrm{~ms}$, dengan selisih waktu setiap stimulus sebesar $20 \mathrm{~ms}$, sehingga terbentuk 12 varian stimulus bunyi. Total stimulus bunyi yang dihasilkan adalah $12 \times 14$ $=168$ stimulus bunyi dengan frekuensi dan waktu titik lekuk yang berbeda-beda. Pada saat tes berlangsungRekayasa pada stimulus bunyi ini dilakukan dengan menggunakan aplikasi Praat.

Tes terdiri dari dua sesi. Pertama, mahasiswa harus menentukan stimulus bunyi yang didengar tergolong nada kedua atau ketiga. Kedua, dua stimulus bunyi yang sama/berbeda waktu dan frekuensi titik lekuknya akan dipasangkan, mahasiswa harus menentukan apakah dua stimulus yang diperdengarkan itu sama/berbeda. Setelah itu, jawaban persepsi mahasiswa diolah menggunakan aplikasi R dan Microsoft Excel.

Indikator hasil penelitian didasarkan pada standar categorical perception yang dikemukakan oleh Liberman. Menurut Liberman, jenis persepsi dapat digolongkan sebagai categorical perception jika memenuhi 3 syarat, pertama, pada tes penggolongan jenis bunyi (tes I), persentase penggolongan antara dua buah stimulus bunyi mengalami perubahan yang drastis, grafik perubahannya terlihat signifikan; kedua, pada grafik perubahan tes II juga terdapat suatu titik dimana nilai persentasenya lebih tinggi dibandingkan dengan titik lainnya; ketiga, kesesuaian antara hasil tes I dan tes II.

Saat waktu dan frekuensi titik lekuk suatu stimulus berada pada titik paling rendah, maka audiens akan mempersepsikan stimulus tersebut sebagai nada kedua. Semakin tinggi nilai waktu dan frekuensi titik lekuk, maka grafik persepsi audiens akan cenderung bergerak memilih nada ketiga. Jika pada suatu titik waktu dan frekuensi tertentu persepsi audiens tibatiba berubah dari memilih nada kedua menjadi nada ketiga dengan batasan yang jelas, maka inilah yang disebut dengan categorical perception. Sebaliknya, jika tidak terdapat perubahan yang signifikan pada persepsi audiens saat mendengar stimulus-stimulus tersebut, dan tidak terdapat batasan yang jelas, maka jenis persepsi ini dapat dikategorikan sebagai continuum perception.

Responden dalam penelitian ini adalah 18 orang mahasiswa tingkat dasar (semester 1) Program Studi Bahasa Mandarin dan Kebudayaan Tiongkok Universitas Al Azhar Indonesia. Sebelum masuk dan belajar Mandarin di UAI, mahasiswa-mahasiswa tersebut belum pernah belajar bahasa mandarin sama sekali, sehingga kemampuan awal mereka dianggap sama. Mahasiswa-mahasiswa ini belajar bahasa Mandarin di UAI baru sekitar 1 semester ( \pm 5 bulan). Selain itu, seluruh mahasiswa yang menjadi responden penelitian bukan merupakan keturunan Tionghoa. Hal ini penting untuk diperhatikan mengingat jika seseorang dapat berkomunikasi menggunakan salah satu bahasa daerah suku Tionghoa sedikit banyak akan mempengaruhi persepsi mereka terhadap nada yang didengar. 


\section{HASIL DAN PEMBAHASAN}

Penelitian terhadap jenis persepsi ini meliputi dua tes, yaitu tes menggolongkan bunyi (tes I) dan tes membedakan dua stimulus bunyi yang didengar (tes II). Pada tes I, peserta penelitian diminta untuk menggolongkan stimulus bunyi yang mereka dengar tergolong nada kedua atau ketiga. Data hasil penelitian menunjukkan bahwa terdapat perubahan persepsi pada stimulus bunyi yang didengar oleh responden. Saat frekuensi titik lekuk sebagai variabel tetap dan waktu sebagai variabel bebas, peserta penelitian mempersepsi stimulus dengan letak frekuensi titik lekuk yang rendah $(10 \mathrm{~Hz}-40 \mathrm{~Hz})$ sebagai nada kedua, dan letak frekuensi titik lekuk yang relatif tinggi $(45 \mathrm{~Hz}-75 \mathrm{~Hz})$ sebagai nada ketiga. Dalam Gambar 1 digambarkan terdapat titik silang yang mencerminkan adanya perubahan persepsi antara nada kedua dan ketiga, untuk selanjutnya titik silang ini disebut sebagai 'batasan persepsi'.

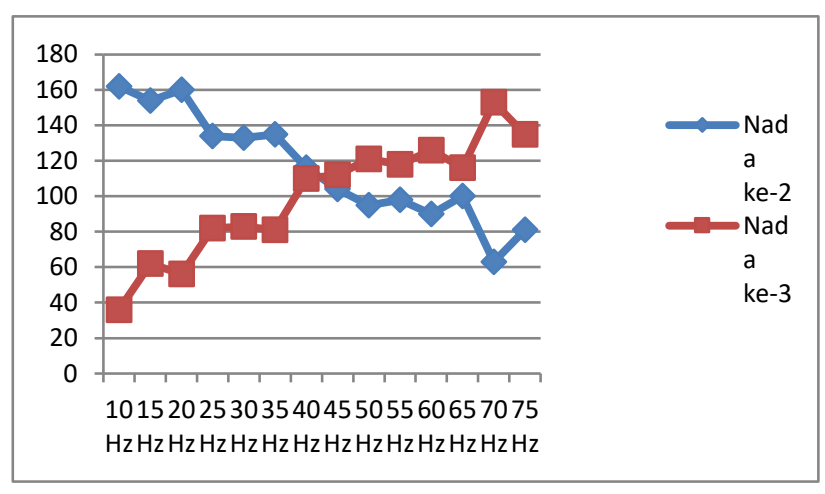

Gambar 1. Data tes I, frekuensi sebagai variabel tetap pada titik lekuk

Sedangkan saat variabel tetap pada titik lekuk adalah waktu, peserta penelitian cenderung mempersepsikan stimulus dengan titik lekuk di 20 ms-120 ms sebagai nada kedua dan stimulus dengan titik lekuk di $140 \mathrm{~ms}-240 \mathrm{~ms}$ sebagai nada ketiga. Dalam grafik 2 juga menunjukkan adanya batasan persepsi peserta penelitian terhadap stimulus bunyi yang didengar.

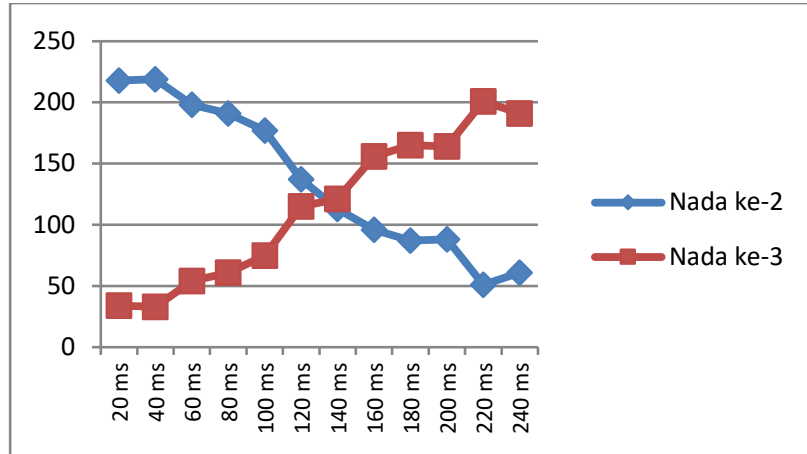

Gambar 2. Data tes I, dengan waktu sebagai variabel tetap pada titik lekuk

Berdasarkan Gambar 1 dan 2, terdapat perubahan atau batasan persepsi pada kedua variabel, namun perubahan tersebut tampak tidak terlalu signifikan. Salah satu faktor penyebabnya adalah selisih frekuensi yang sangat kecil antara stimulus yang satu dengan lainnya, yakni hanya $5 \mathrm{~Hz}$, sehingga diperlukan kesensitifan pendengaran yang tinggi untuk menggolongkan dan membedakan stimulusstimulus bunyi tersebut.

Gambar 1 dan 2 juga menunjukkan peserta lebih sensitif terhadap stimulus dengan waktu sebagai variabel tetap dibandingkan dengan frekuensi sebagai variabel tetap, ini terlihat dari selisih nilai antara persepsi nada kedua dengan nada ketiga yang sedikit lebih besar pada Gambar 2.

Pada tes II, peserta diminta untuk menentukan apakah sepasang stimulus bunyi yang didengar sama atau berbeda. Hasil penelitian menunjukkan, baik variabel tetap waktu maupun frekuensi, persentase ketepatan jawaban peserta sebagian besar dibawah $50 \%$. Gambar 3 dan 4 juga menunjukkan tidak adanya perubahan yang sangat signifikan pada persepsi responden.

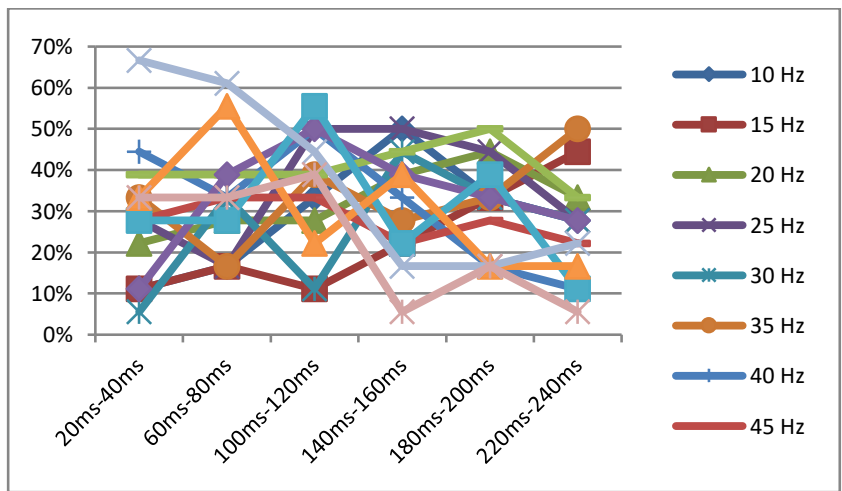

Gambar 3. Data tes II, dengan waktu sebagai variabel tetap pada titik lekuk 


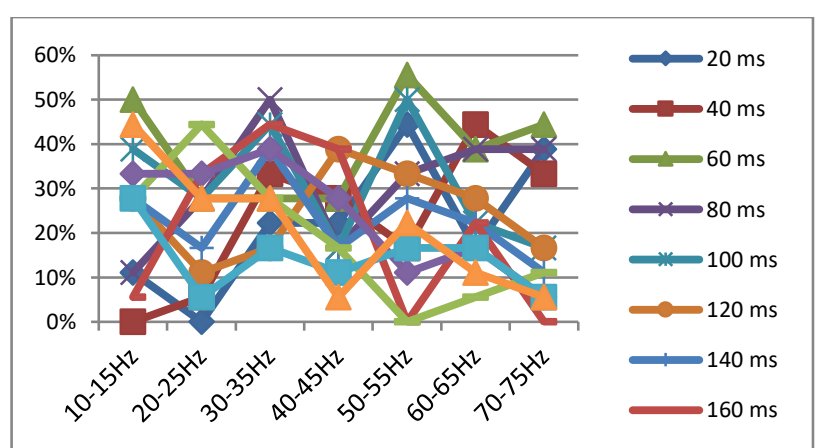

Gambar 4. Data tes II, dengan frekuensi sebagai variabel tetap pada titik lekuk

Berdasarkan Gambar 4, meskipun pada frekuensi $30-35 \mathrm{~Hz}$ dan $50-55 \mathrm{~Hz}$ persentase ketepatan jawaban peserta penelitian cenderung naik, namun pergerakannya masih dianggap tidak signifikan dikarenakan pada variabel waktu tertentu persentasenya masih jauh dibawah 50\%. Ini menunjukkan bahwa, pada tes II tidak ditemukan batasan persepsi yang merupakan salah satu ciri categorical perception.

Menurut Liberman, suatu persepsi digolongkan categorical perception jika memenuhi 3 syarat, yakni : pertama, pada tes penggolongan jenis bunyi (tes I), persentase penggolongan antara dua buah stimulus bunyi terdapat perubahan yang signifikan, terdapat batasan persepsi dan grafik perubahannya terlihat signifikan; kedua, pada grafik perubahan tes II juga terdapat suatu titik dimana nilai persentasenya lebih tinggi dan signifikan dibandingkan dengan titik lainnya; ketiga, kesesuaian antara hasil tes I dan II.

Merujuk pada data penelitian diatas, pada tes I terdapat kecenderungan categorical perception, yakni adanya kecenderungan batasan persepsi pada titik lekuk 40-45 Hz dan 120-140 ms. Namun, pada tes II, tidak terdapat titik dimana persentasenya lebih tinggi dan signifikan dibanding titik yang lainnya. Ini menunjukkan tidak adanya kesesuaian antara hasil tes I dan II. Dari tiga syarat standar categorical perception yang dikemukakan Liberman diatas, diketahui hanya satu hasil tes yang memenuhi standar. Oleh karena itu, dapat disimpulkan bahwa jenis persepsi mahasiswa tingkat dasar dalam membedakan nada kedua dan ketiga tergolong jenis kategori kontinuitas (continuum perception). Mahasiswa tingkat dasar dianggap belum memiliki kepekaan yang tinggi dalam membedakan stimulus nada turun-naik yang menjadi ciri dari nada kedua dan ketiga.

\section{KESIMPULAN}

Penelitian dengan teori categorical perception bertujuan untuk mengetahui bagaimana mahasiswa mempersepsi dan membedakan stimulus bunyi yang didengar serta tingkat kepekaan mereka terhadap nada atau bunyi tertentu. Stimulus bunyi yang diperdengarkan dalam penelitian ini adalah bunyi turun-naik (降升调) dengan perubahan waktu dan frekuensi titik lekuk yang bervariasi.

Hasil penelitian pada mahasiswa dengan kemampuan berbahasa Mandarin tingkat dasar menunjukkan persepsi mahasiswa pada bunyi turunnaik yang menjadi ciri dari nada kedua dan ketiga adalah jenis persepsi kontinuitas (continuum perception). Ini dikarenakan grafik hasil tes II menunjukkan tidak terdapat suatu titik dimana nilai persentasenya lebih tinggi dan signifikan dibandingkan dengan titik lainnya. Selain itu juga tidak adanya kesesuaian antara hasil tes I dan tes II. Ini juga berarti mahasiswa dengan kemampuan berbahasa Mandarin tingkat dasar belum memiliki kepekaan yang tinggi dalam membedakan bunyi atau nada.

Penelitian berpusat pada persepsi mahasiswa terhadap nada kedua dan ketiga yang merupakan jenis nada yang dianggap cukup sulit dikuasai oleh pembelajar bahasa Mandarin. Sedangkan nada pertama dan nada keempat belum termasuk didalamnya. Penulis berharap kedepannya fokus penelitian dapat diperluas dan diperdalam lagi yakni mengenai persepsi dan juga pelafalan mahasiswa terhadap empat nada yang ada dalam bahasa Mandarin.

\section{REFERENSI}

[1] W. Gongping, An Experimental Study on Errors in Articulating 3+3 Tone Sandhi of Bi-syllable of Mandarin Produced by Overseas Indonesian Students of Chinese Origin, 暨南大学华文学 院学报, Vol 4, No 4, pp 9-20, 2004.

[2] W. Maolin, 印尼华裔留学生汉语声调习得分 析, 暨南大学华文学院学报, Vol 2, pp 10-15, 2006.

[3] W Zongji, L Maolan, 实验语音学概要, Higher Education Press, Beijing, 1989.

[4] L. Juan. Perceiving the boundary between the lexical rising tone and the falling-rising tone'. Joy of research a festschrift in honor of Professor William S-Y. Wang on his seventieth 
birthday, Nankai University Press, pp. 222-233, 2004.

[5] Z. Linjun, On the influence of Native Language on the Categorical Perception of Chinese Tones . 华文教学与研究TCSOL Studies, Vol. 2, No. 22010, pp. 15-20, 2010.

[6] L. Leqin. M. S. Thesis, A Probe into the Category Perception of Mandarin Tones of Vietnamese and Thai Students, Guangxi Normal University, Nanning, 2014.

[7 T. Chongzi. "The Experiments of Identification and Discrimination of Chinese Tones for Indonesian Students". M. S. Thesis, Guangxi Normal University, Nanning, 2017.
[8] W. Yunjia, L Meijing, The Effects of Tone Pattern and Register in Perceptions of Tone 2 and Tone 3 in Mandarin, Acta Psychologica Sinica, Vol. 42, No.9, pp 899-908, 2010.

[9] W. Yunjia, L Meijing. The Perceptions of Tone 2 and Tone 3 in Mandarin by Korean Native Speakers, Language Teaching and Linguistic Studies, Vol 1, pp.17-25. 2011.

[10] N.L. Qadriani, M. TCSOL Thesis. "The Perception and Pronounce of Tone 2 and Tone 3 in Mandarin by Indonesian Students", Shanghai International Studies University, Shanghai, 2017. 